\title{
Physiological and Biochemical Studies on Streptomycin Dependence in Escherichia coli
}

\author{
By C. R. SPOT'TS* \\ Department of Bacteriology, University of California, Berkeley, California, U.S.A.
}

(Received 4 September 1961)

\section{SUMMARY}

The exponential growth rate of a streptomycin-dependent strain of Escherichia coli was proportional to streptomycin concentration until a critical concentration was reached, above which it was independent of streptomycin concentration. The value of the critical concentration changed with a change either in the carbon source, or in the temperature of cultivation. Below the critical concentration, the macromolecular composition of the cells was affected by the external streptomycin concentration: as this decreased, the ribonucleic acid (RNA) content of the organisms increased, and the protein content decreased. When external streptomycin was removed, streptomycin-dependent organisms continued to grow for many hours. Growth was at first exponential, the extent and duration of this phase being functions of the concentration of streptomycin to which the organisms had previously been exposed. This phase was followed by a much longer period of arithmetic growth, unaccompanied by cell division, during which the organisms elongated progressively. Growth in the absence of streptomycin caused changes in the macromolecular composition of the organisms which were similar in nature to those produced by growth with a subcritical concentration of streptomycin, but much more pronounced. The greatly increased total RNA content of these organisms was not accompanied by grossly detectable qualitative changes in the RNA content of the organisms. In the absence of streptomycin, the synthesis of some enzymes was either arrested or decreased in rate; the synthesis of others was unaffected. This leads to an imbalance in the enzymic constitution. These differential effects on enzyme synthesis appeared to be random. Growth in absence of streptomycin did not seem to affect deoxyribonucleic acid (DNA) synthesis or function, as shown by the ability of a lysogenic streptomycin-dependent strain to produce infective phage under such conditions. The re-introduction of streptomycin to a culture growing arithmetically as a consequence of streptomycin depletion caused a resumption of DNA synthesis at the normal exponential rate. The rate of protein synthesis also soon increased, but attained its normal exponential rate more slowly. RNA synthesis was wholly arrested until the RNA content of the organisms had fallen to a normal value, and then resumed at the normal exponential rate. Grown in the presence of a greater than critical concentration of streptomycin, the streptomycin-dependent organism bound irreversibly about 250,000 molecules of streptomycin, half of which could be extracted with hot water, and the remainder with hot perchloric acid. A new hypothesis concerning the location and nature of the genetically determined intracellular lesion which results in streptomycin dependence is developed on the basis of these facts.

* Present address : Laboratoire d'Enzymologie, Centre National de la Recherche Scientifique, Gif-sur-Yvette (Seine-et-Oise), France. 


\section{IN'TRODUCTION}

Not long after the discovery of streptomycin, Miller \& Bonhoff (1947) reported the isolation from a streptomycin-sensitive meningococcus of a mutant strain which had an absolute requirement for streptomycin as a growth factor. Similar streptomycin-dependent strains have subsequently been isolated from many other naturally streptomycin-sensitive bacterial species; there are thus good reasons to believe that mutation to an absolute dependence on this substance is a widespread genetic potentiality of bacteria. Dependence on streptomycin is one of three alternative genetically determined responses of a bacterium to the presence of streptomycin in its environment; the two other possible responses being sensitivity and resistance. The category of resistance includes several different states, which are distinguishable from one ancther both genetically and phenotypically (Watanabe \& Watanabe, 1959 $a, b$; Hashimoto, 1960; Matney, Goldschmidt \& Bausun, 1960); but the available data suggest that dependence is monogenically determined, and hence a phenotypically uniform state. In Escherichia coli, genetic analysis has shown that sensitivity, dependence and single-step resistance to a high concentration of streptomycin ('indifference') are determined by multiple alleles at a single locus, known as the Sm locus (Newcombe \& Nyholm, 1950; Lennox, 1955 ; Hashimoto 1960). This genetic fact implies that the three phenotypic states in question are all determined, in the last analysis, by alternative structural modifications of a single chemical substance within the cell, and that each of these modifications has a series of specific functional consequences which cause the cell to respond in a specific way to streptomycin.

Attempts to elucidate the mode of action of streptomycin have led to many different studies of its physiological and biochemical effects on bacteria, and a considerable number of divergent hypotheses have been put forward on the basis of the resultant findings. Most of these studies have been done with strains of the sensitive and resistant phenotypes. However, the genetic facts which have been outlined above suggest that analysis of the relatively neglected, bizarre and clinically unimportant phenomenon of dependence has an equal intrinsic probability of furnishing clues to the mechanism of streptomycin action in the bacterial cell. Such reasoning resulted in the investigation of the dependent phenotype of Escherichia coli which will be described in the present paper.

The principal facts established by earlier work about the physiological and biochemical properties of streptomycin-dependent bacteria may be summarized as follows. (1) The growth rate of a dependent strain is a direct function of the concentration of streptomycin in the medium; the amount required to permit a maximal growth rate is very substantial, generally of the order of several hundred $\mu \mathrm{g} . / \mathrm{ml}$. (Paine \& Finland, 1948; Schaeffer, 1950). (2) When streptomycin is removed from the medium, cell division socn ceases; the amount of residual cell division is a function of the concentration of streptomycin in which the cells were previously grown (Demerec, Wallace, Witkin \& Bertani, 1949; Bertani, 1951). After cell division ceases, further arithmetic growth occurs; the organisms increase in length, and nuclear divisions continue (Delaport, 1949; Demerec et al. 1949; Schaeffer, 1950; Simon, 1955). (3) In the absence of streptomycin, the synthesis of some enzymes ceases. Generally, the oxidative capacity of a dependent culture does not 
increase in the absence of streptomycin (Schaeffer, 1949 $a, b, 1950,1952$ ), and the synthesis of active cytochrome oxidase is blocked under these conditions (Engelberg \& Artman, 1961). The same studies also showed, however, that the synthesis of certain enzymes associated with fermentative activity was not influenced by streptomycin deprivation. (4) The growth of streptomycin-dependent organisms does not diminish appreciably the streptomycin content of the medium (Rubin \& Steinglass 1951). Attempts to show uptake of streptomycin by streptomycin-dependent organisms during growth have so far failed (Szybalski \& Mashima, 1959); but it should be noted that the sensitivity of these measurements was not sufficiently great to exclude the intracellular accumulation of very small amounts.

\section{METHOIS}

Organisms. The strains used in all experiments were derived from Escherichia coli strain K-12. Strain W1709 was obtained from Dr J. Lederberg; it requires threonine, leucine, thiamine and streptomycin for growth, and is unable to grow at the expense of lactose or maltose. The failure to use lactose is a consequence of the inability of this strain to form the permease necessary for entry of lactose into the cell. Strain W1709 is also lysogenic for bacteriophage $\lambda$. Strain CS-1 is a $\beta$ galactosidase constitutive recombinant selected from a mating between $\mathrm{W} 1709\left(\mathrm{~F}^{-}\right)$ and W3300 (a Hayes-type Hfr which is streptomycin-sensitive, constitutive for the production of $\beta$-galactosidase and requires thiamine). Strain W3300 was obtained from Dr A. J. Clark, Dept. of Bacteriology, University of California, Berkeley, California, U.S.A. The recombinant was selected from the mating mixture by plating on minimal agar supplemented with streptomycin + thiamine and containing lactose as sole carbon source. Strain CS-2 is a spontaneous mutant of W1709 which has regained the ability to grow with lactose as sole carbon source, and produces $\beta$-galactosidase inducibly. It was isolated by spreading about $10^{6}$ organisms from a glucose-grown culture of strain W 1709 on plates of a defined medium containing lactose as sole carbon source, and supplemented with threonine + leucine + thiamine + streptomycin. On this medium, CS-2 forms large colonies, whereas the parental strain W1709 does not grow appreciably.

Media. The defined medium used for all growth experiments had a mineral base of the following composition: $\mathrm{NH}_{4} \mathrm{Cl}, 0 \cdot 1 \%(\mathrm{w} / \mathrm{v}) ; \mathrm{MgSO}_{4} \cdot 7 \mathrm{H}_{2} \mathrm{O}, 0.025 \%(\mathrm{w} / \mathrm{v})$; $\mathrm{KH}_{2} \mathrm{PO}_{4}+\mathrm{Na}_{2} \mathrm{HPO}_{4}$ buffer $(\mathrm{pH} 7 \cdot 0), 0 \cdot 05 \mathrm{M}$. After sterilization, this base was supplemented with separately sterilized solutions of required growth factors, carbon source and streptomycin. The growth factors were used at the following final concentrations: DL-threonine, $100 \mu \mathrm{g} . / \mathrm{ml}$.; DL-leucine, $100 \mu \mathrm{g} . / \mathrm{ml}$.; thiamine hydrochloride, $0.5 \mu \mathrm{g} . / \mathrm{ml}$. The carbon source (glucose, sodium succinate or glycerol) was used at a final concentration of $0 \cdot 4 \%(\mathrm{w} / \mathrm{v})$. The concentrations of streptomycin used are specified for each experiment. The complex medium, used for estimating number of viable organisms, had the following composition: Difco yeast extract, $0.5 \%(\mathrm{w} / \mathrm{v})$; Difco peptone, $0.3 \%(\mathrm{w} / \mathrm{v}) ; \mathrm{KH}_{2} \mathrm{PO}_{4}+\mathrm{Na}_{2} \mathrm{HPO}_{4}$ buffer $(\mathrm{pH} \mathbf{7} \cdot 0)$, $0.02 \mathrm{M} ;$ agar, $2.0 \%(\mathrm{w} / \mathrm{v})$.

Methods of cultivation and measurement of growth. Cultures were grown in shallow layers in Erlenmeyer flasks incubated on a rotary shaker, and growth was estimated turbidometrically with a Klett-Summerson colorimeter. Klett readings and bacterial 
numbers were proportional up to a Klett reading of 50; when the measured optical density exceeded this value, a correction curve was used to determine the true population density. A Klett reading of 50 corresponded to a viable count of $3.7 \times$ $10^{8} \mathrm{bacteria} / \mathrm{ml}$. (equiv. to $0.12 \mathrm{mg}$. dry wt. cell material $/ \mathrm{ml}$.) in exponentially growing cultures. Unless otherw se stated, all growth experiments were done at $30^{\circ}$.

When a growth experiment was done in the absence of streptomycin, or when the streptomycin concentration was changed during the course of an experiment, the bacteria were carefully washed to remove absorbed streptomycin by two successive centrifugations in $\mathrm{M} / 20$ phosphate buffer $(\mathrm{pH} 7 \cdot 0)$. 'These operations were carried out as rapidly as possible in sterile screw-capped tubes at room temperature. The efficiency of this procedure in the removal of ${ }^{14} \mathrm{C}$-streptomycin is shown in Table 1. Bacteria treated in this way imniediately resumed exponential growth when placed in fresh pre-warmed medium of the same composition as that from which they had been removed.

\section{Table 1. Removal of adsorbed streptomycin by washing}

\begin{tabular}{|c|c|c|c|c|c|}
\hline & \multirow{3}{*}{$\begin{array}{l}\text { Streptomycin } \\
\text { added } \\
(\mu \mathrm{g} . / \mathrm{ml} .) \\
\mathbf{6 3 0}\end{array}$} & $\begin{array}{l}\text { Supernatant } \\
\text { fluid }\end{array}$ & $\begin{array}{l}\text { First } \\
\text { wash }\end{array}$ & $\begin{array}{l}\text { Second } \\
\text { wash }\end{array}$ & \multirow{3}{*}{$\begin{array}{c}\text { Total } \\
\text { recovery } \\
(\%) \\
100\end{array}$} \\
\hline Medium & & \multicolumn{3}{|c|}{$\begin{array}{l}\text { Streptomycin recovered after sedi- } \\
\text { mentation of cells }(\mu \mathrm{g} . / \mathrm{ml} .)\end{array}$} & \\
\hline $\begin{array}{c}0 \cdot() 1 \mathrm{~m}-\mathrm{phosphate} \\
\text { buffer }(\mathrm{pH} 7 \cdot 0)\end{array}$ & & 618 & $14 \cdot 2$ & 0.6 & \\
\hline Defined & 350 & 347 & $4 \cdot 8$ & $0 \cdot 1$ & 100 \\
\hline Defined & 20 & $16 \cdot 4$ & $3 \cdot 6$ & $1 \cdot 0$ & 105 \\
\hline
\end{tabular}

Analytical methods. The proten content of the bacteria was determined by the method of Lowry, Rosebrough, Farr \& Randall (1951). For the determination of nucleic acids, bacteria were fractionated with perchloric acid by the procedure of Burton (1956), after which ribon cleic acid (RNA) and deoxyribonucleic acid (DNA) were determined in the hot acid-soluble fraction by the procedures of Mejbaum (Schneider, 1957) and Burton (1956), respectively.

Preparation of cell-free extracts and measurement of enzymic activity. Bacteria which were to be used for the preparation of enzymically active extracts were harvested by centrifugation in the cold and were washed twice with cold phosphate buffer $(\mathrm{M} / \mathbf{1 0 0} ; \mathrm{pH} 7 \cdot 5)$. The extracts were prepared by suspending the bacteria in ten times their own weight of the same buffer and treating them in the French Pressure Cell (American Instrument Company, Silver Springs, Maryland, U.S.A.) at a pressure of $20,000 \mathrm{lb} . / \mathrm{sq}$. in. Unbroken bacteria and the large cellular debris were removed by centrifugation for $20 \mathrm{~min}$. at $7000 \mathrm{~g}$ in the cold. A portion of the crude extract thus prepared was then subjected to further centrifugation at $100,000 \mathrm{~g}$ for $90 \mathrm{~min}$. The supernatant fluid from this centrifugation (soluble fraction) was carefully decanted; the sediment (particulate fraction) was washed with the same buffer by centrifugation. In certain instances enzyme activity was determined in bacteria ruptured with toluene. In such cases, $0.1 \mathrm{ml}$. toluene was added directly to a sample of the culture and this sample was then shaken for 
$10 \mathrm{~min}$. at $30^{\circ}$. Enzymic activities were measured directly on portions of this toluenized suspension.

Enzymic assays were carried out according to standard procedures. Manometric measurements were done in the Warburg apparatus at $30^{\circ}$. Spectrophotometric assays were done in the Beckman model DU spectrophotometer fitted with a circulating water bath which maintained the cuvette compartment at $30^{\circ}$. The enzymes measured, the fraction of cell-extract routinely used for assay, the measurement of activity for each enzyme, and the reference to the method used are listed in Table 2. In all cases enzymic activity was determined by the measurement of the initial rate of reaction under conditions in which enzyme concentration was the rate-limiting factor.

Table 2. Techniques employed for the analysis of enzymic activities

\begin{tabular}{|c|c|c|c|}
\hline Enzyme & $\begin{array}{l}\text { Cell fraction } \\
\text { assayed }\end{array}$ & $\begin{array}{l}\text { Measurement of } \\
\text { activity }\end{array}$ & Reference \\
\hline Threonine deaminase & Toluenized cells & Keto-acid formation & $\begin{array}{l}\text { Pardee \& Prestidge, } \\
1955\end{array}$ \\
\hline $\begin{array}{l}\text { Glutamic } \\
\text { dehydrogenase }\end{array}$ & Soluble & TPN reduction & Strecker, 1955 \\
\hline $\begin{array}{l}\text { 5-Dehydroshikimic } \\
\text { reductase }\end{array}$ & Soluble & TPN reduction & $\underset{1955}{\text { Yaniv \& Gilvarg, }}$ \\
\hline $\begin{array}{l}\text { Tryptophan } \\
\text { synthetase }\end{array}$ & Crude extract & Indole disappearance & Yanofsky, 1955 \\
\hline $\begin{array}{l}\text { Dihydroorotic } \\
\text { dehydrogenase }\end{array}$ & $\begin{array}{l}\text { Particulate or crude } \\
\text { extract }\end{array}$ & $\begin{array}{l}\text { Orotic acid pro- } \\
\text { duction }\end{array}$ & $\begin{array}{l}\text { Yates \& Pardee, } \\
1957\end{array}$ \\
\hline $\begin{array}{l}\text { Isocitric dehydro- } \\
\text { genase }\end{array}$ & Soluble & TPN reduction & Barban \& Ajl, 1952 \\
\hline DPNH oxidase & $\begin{array}{l}\text { Particulate or crude } \\
\text { extract }\end{array}$ & DPNH oxidation & Slater, 1950 \\
\hline $\begin{array}{l}\text { Succinic dehydro- } \\
\text { genase }\end{array}$ & Particulate & DIP* reduction & $\begin{array}{l}\text { Slater \& Bonner, } \\
1952 ; \text { Price \& } \\
\text { Thimann, 1954 }\end{array}$ \\
\hline $\begin{array}{l}\text { Glucose-6-phosphate } \\
\text { dehydrogenase }\end{array}$ & Soluble & TPN reduction & DeMoss, 1955 \\
\hline$\beta$-Galactosidase & $\begin{array}{l}\text { Crude extract or } \\
\text { toluenized cells }\end{array}$ & ONPG $†$ hydrolysis & Lederberg, 1950 \\
\hline
\end{tabular}

Preparations of fractions for analysis of intracellular $R \mathbf{N A}$ distribution. Bacteria were harvested and fractionated by a procedure adapted from that used by Bolton, Britten, Cowie \& Roberts (1958) and Bolton et al.(1959). The bacteria were harvested, washed twice with TSM buffer (2-amino-2-hydroxymethylpropane-1:3-diol, $0 \cdot 01 \mathrm{M}$; succinic acid, $0.004 \mathrm{M}$; magnesium acetate, $0.01 \mathrm{M} ; \mathrm{pH} 7 \cdot 6$ ), and resuspended in the same buffer at a concentration equivalent to about $20 \mathrm{mg}$. dry wt. $/ \mathrm{ml}$. Crude extracts were prepared in the French Pressure Cell as described, and this crude extract then subjected to differential centrifugations which yielded three fractions: the membrane fraction consisting of material sedimented in $15 \mathrm{~min}$. at $100,000 \mathrm{~g}$; the ribosome fraction consisting of the material sedimented in $120 \mathrm{~min}$. but not in $15 \mathrm{~min}$. at $100,000 \mathrm{~g}$; the soluble fraction consisting of the material not sedimented in $120 \mathrm{~min}$. at $100,000 \mathrm{~g}$. Ribosomes were washed by resuspension in TSM buffer and recentrifugation for $120 \mathrm{~min}$. at $100,000 \mathrm{~g}$. 
Ultracentrifugal analyses were performed on crude extracts in the Spinco model E analytical Ultracentrifuge.

Chemicals. ${ }^{14} \mathrm{C}$-streptomycin $\left(\mathrm{CaCl}_{2}\right.$ salt) uniformly labelled with a specific activity of $0.079 \mu \mathrm{c} / \mathrm{mg}$. of streptomycin base was a gift from Dr B. Woodruff (Merck, Sharp \& Dohme, Inc., Rahway, New Jersey, U.S.A.). Isopropyl- $\beta$-Dthiogalactoside (IPTG) was a gilt from Dr A. B. Pardee.

\section{RESULTS}

\section{Binding of streptomycin during growth by streptomycin-dependent organisms}

A culture of Escherichia coli strain W 1709 was allowed to grow for ten to twelve generations in the defined medium containing $560 \mu \mathrm{g} .{ }^{14} \mathrm{C}$-streptomycin $/ \mathrm{ml}$. The bacteria were then harvested, washed three times by centrifugation with $\mathrm{M} / \mathbf{2 0}$ phosphate buffer, and then collected in quantities equivalent to $1.0-1.5 \mathrm{mg}$. dry wt. on Millipore filters. They were further washed on the filters with the same buffer containing $50 \mu \mathrm{g}$. non-radioactive streptomycin $/ \mathrm{ml}$. until the washings no longer possessed detectable radioactivity. 'These samples were then dried and their radioactivity determined. This experiment showed that the amount of bound streptomycin corresponded to about 250,000 molecules/bacterium. Extraction of the bacteria with hot water $\left(95^{\circ}, 10 \mathrm{~min}\right.$.) removed $50 \%$ of the bound streptomycin. The remainder could be extracted by hot perchloric acid $\left(0.5 \mathrm{~N}, 70^{\circ}, 15 \mathrm{~min}\right.$.) but not by cold perchloric acid $\left(0 \cdot 5 \mathrm{~s}, 0^{\circ}, 15 \mathrm{~min}\right.$.).

\section{Effect of streptomycin concentration on growth rate}

The strains of Escherichia coli used in this work grew exponentially in the defined medium provided that the concentration of streptomycin was greater than $10 \mu \mathrm{g} . / \mathrm{ml}$. When glycerol or succinate was the carbon source, the growth rate was a direct function of the streptomycin concentration up to about $100 \mu \mathrm{g} . / \mathrm{ml}$., at which value streptomycin was no longer the rate-limiting nutrient. When glucose was the carbon source, streptomycin remained rate-limiting up to about $250 \mu \mathrm{g} . / \mathrm{ml}$. At ratelimiting concentrations of streptomycin, the growth rate was independent of the nature of the carbon source. These effects of streptomycin concentration are illustrated in Fig. 1. The growth rate in this figure is expressed as $k$, the exponential growth constant, calculated by means of the equation: $k=\ln 2 / G$, where $G$ is the generation time in hours. For the purposes of this paper, we shall define as 'normal bacteria' of a streptomycin-dependent strain, bacteria which are growing exponentially in a medium containing \&, concentration of streptomycin that is equal to or greater than the rate-limiting concentration for growth. We shall define as a 'critical concentration' of strefitomycin that concentration which is just sufficient to support growth at maximal ate in any given medium.

\section{Effect of streptomycin concentration on cellular composition}

Cultures of Escherichia coli strain W1709 were grown in the defined medium with glycerol as carbon-source, and with streptomycin concentrations which ranged from 10 to $1000 \mu \mathrm{g}$. $/ \mathrm{ml}$, thus including both sub- and supra-critical concentrations. While in the course of exponential growth, the bacteria from each culture were harvested and analysed to determine their content of RNA, DNA and protein. At subcritical concen rations of streptomycin, the RNA content of the 


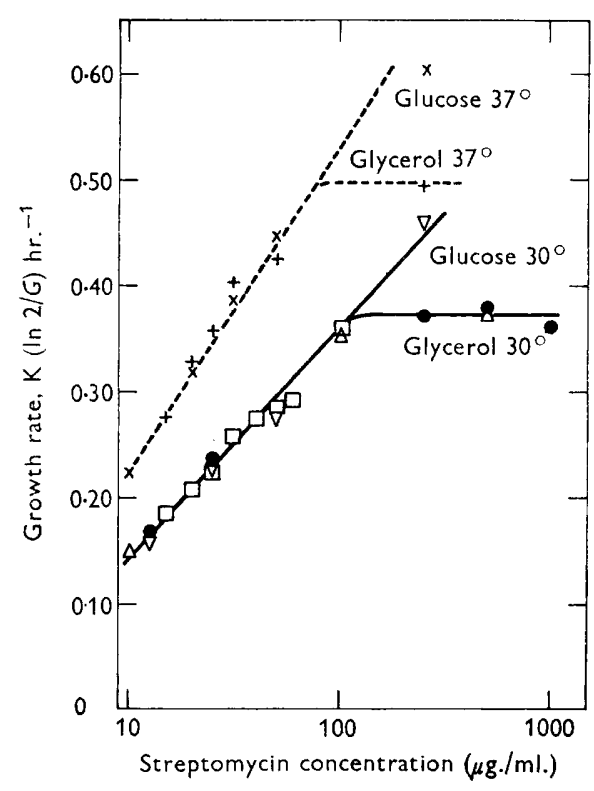

Fig. 1

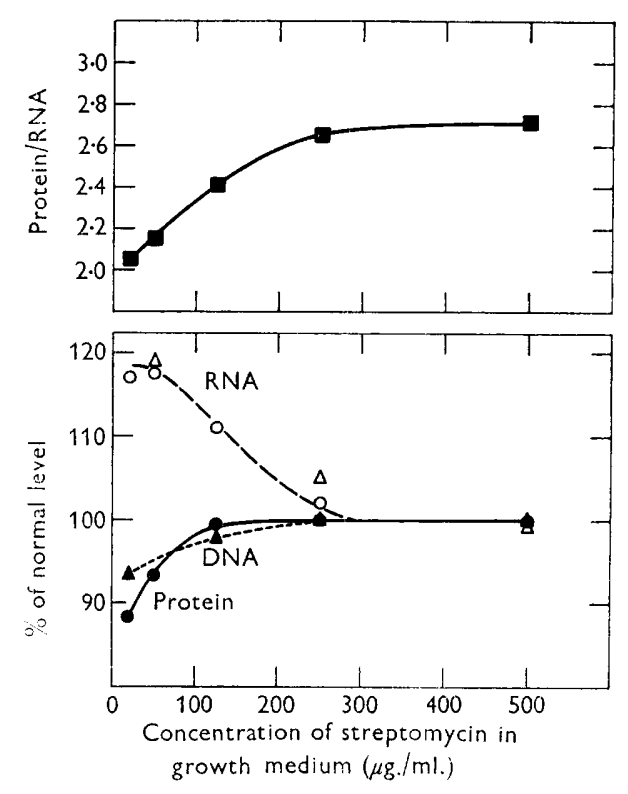

Fig. 2

Fig. 1. The effect of streptomycin concentration on the growth rate of Escherichia coli strain CS-2 in defined medium with different carbon sources. $(\times)$ glucose, $37^{\circ} ;(+)$ glycerol, $37^{\circ} ;(\square, \nabla)$ glucose, $30^{\circ} ;(\triangle, \odot)$ glycerol, $30^{\circ}$.

Fig. 2. The effect of streptomycin concentration on the macromolecular composition of Escherichia coli strain CS-1. The concentration of each component is expressed as percentage of the normal dry wt. of cells grown in media containing 500-1000 $\mu \mathrm{g}$. streptomycin $/ \mathrm{ml}$.

bacteria was higher and the protein content lower than in bacteria grown with supra-critical streptomycin concentrations. The DNA content was only slightly affected by changes in streptomycin concentration, decreasing slightly at very low concentrations. These variations in cellular composition as a function of streptomycin concentration are shown in Fig. 2.

\section{The phenomenon of deprived growth}

When bacteria were harvested during the exponential phase of growth, washed to remove adsorbed streptomycin and then re-inoculated into a streptomycin-free medium of otherwise identical composition, a characteristic sequence of events took place. The cell mass increased exponentially at the maximal rate for a short period, the duration of which was directly proportional to the streptomycin concentration of the medium from which the bacteria had been taken. This was followed by a period of growth at a progressively declining rate which lasted for 1-2 $\mathrm{hr}$. Finally, there was a period of arithmetic growth which lasted for 16-20 hr., during which the cell mass increased about sixfold. The bacteria then entered a stationary phase. The extent of growth, i.e. the ratio between the final and the initial cell mass, was directly proportional to the streptomycin concentration in which the bacteria were grown, and was the same for all cultures grown at a given streptomycin concentration. This growth in the absence of streptomycin will be termed 'deprived 
growth'; and bacteria in the period of arithmetic deprived growth will be termed 'deprived bacteria'. The effects of streptomycin concentration on subsequent deprived growth are shown in Fig. 3. In the graphical presentation of the data from experiments on deprived growth (as in Fig. 3), it is convenient to express the increase either in cell mass, or in chemical constituents of the cell, as a relative increase, rather than as an absolute one. This device permits a direct comparison of the data from different experiments by eliminating the otherwise confusing graphical effects caused by differe:nces in inoculum size.

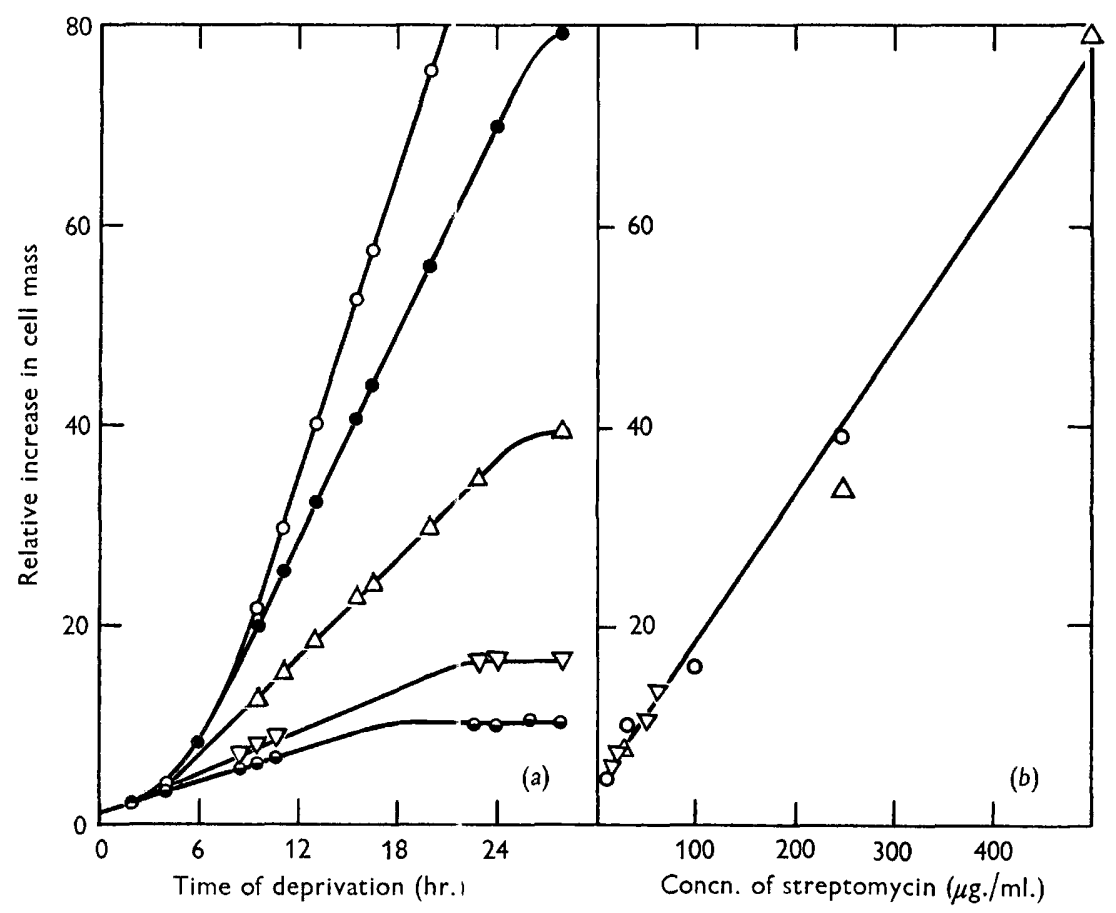

Fig. 3. The effect of streptomycin concentration on deprived growth of Escherichia coli strain CS-1. (a) Deprived-grow th curves of cultures pre-grown in glycerol defined medium containing streptomycin ct concentrations of $1000 \mu \mathrm{g} . / \mathrm{ml}$. (O); $500 \mu \mathrm{g} . / \mathrm{ml}$.

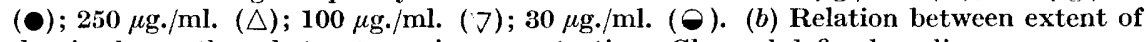
deprived growth and streptomyein concentration. Glycerol defined medium.

Viable counts performed during the period of deprived growth revealed an initial short period of multiplication, roughly coincident with the period of exponential growth. Thereafter, the number of colony-forming units in the culture remained constant throughout the period of arithmetic growth and only began to decrease several hours after the onset of the stationary phase. The relation between growth and viable count is shown in Fig. 4. As deprived growth proceeded all of the bacteria became converted into filaments which eventually attained a length about ten times the normal length. Each of these filaments contained several nuclear bodies, generally 6 or 8 by the time the stationary phase was reached.

Analysis of cellular composition during the initial period of deprived growth revealed drastic changes in relative concentrations of different macromolecular constituents. These changes were qualitatively similar to those which resulted from 


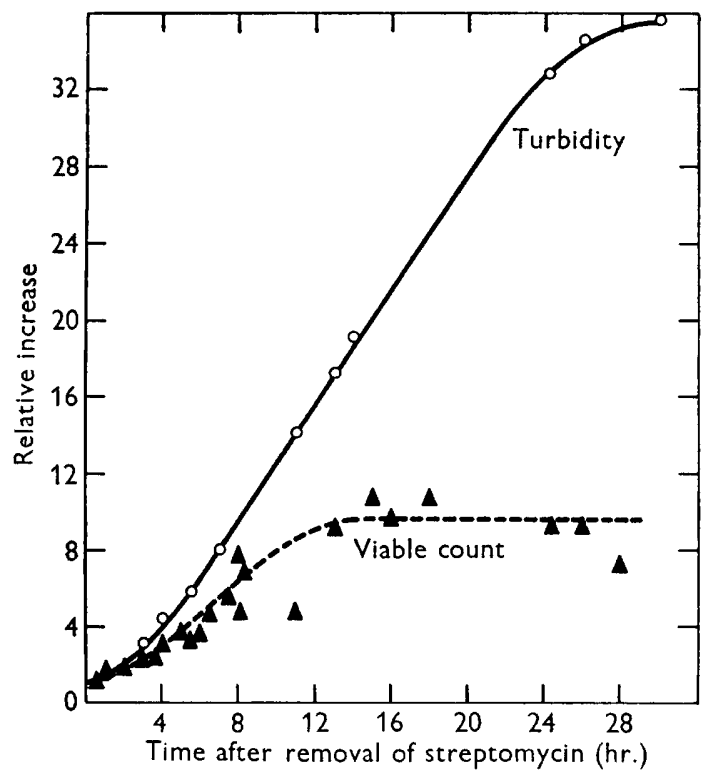

Fig. 4

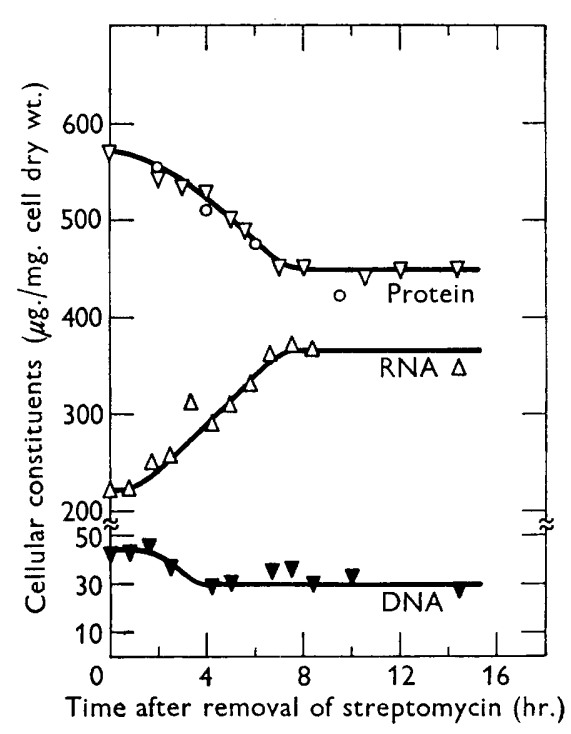

Fig. 5

Fig. 4. Increase in colony-forming units during deprived growth of Escherichia coli strain CS-1. The culture was grown in glycerol defined medium containing $250 \mu \mathrm{g}$. streptomycin $/ \mathrm{ml}$.

Fig. 5. Change in concentration of cellular constituents during deprived growth of Escherichia coli strain CS-1. The culture was grown in glycerol defined medium containing $250 \mu \mathrm{g}$. streptomycin $/ \mathrm{ml}$.

growth in media with rate-limiting streptomycin concentrations, but ultimately attained a much greater magnitude. They ceased shortly after arithmetic growth began, and thereafter the macromolecular composition of the bacteria remained constant (Fig. 5). The RNA/protein ratio in streptomycin-deprived bacteria reached a value more than twice that of normal cells. Although this ratio is directly related to the streptomycin concentration in bacteria growing exponentially in subcritical concentrations of streptomycin, it never exceeded a value $\mathbf{1 \cdot 3}$ times that of normal bacteria at the lowest concentrations of streptomycin which would support exponential growth (see Fig. 3).

Spectrophotometric analysis of the medium during deprived growth revealed no significant excretion of material which absorbed in the ultraviolet region.

\section{Effects of streptomycin deprivation on the nature and distribution of $R N A$ within the cell}

A comparison of extracts prepared from normal and deprived bacteria showed that the abnormally high concentration of RNA in deprived bacteria was not accompanied by any gross changes in the intracellular distribution of RNA. In both kinds of bacteria, $12-13 \%$ of the total RNA was in the soluble fraction, the remainder being associated with particulate (i.e. ribosomal) material. Analysis of washed ribosomal particles from normal and deprived bacteria showed no differences 
in gross chemical composition (Table 3). The values found in both instances agree with values previously pul)lished for the ribosomes of Escherichia coli (Bolton et al. 1958; Tissières, Watson, Schlessinger \& Hollingworth, 1959). Ultracentrifugal analyses of crude extracts prepered from normal and deprived bacteria showed no qualitative differences in the distribution of macromolecular components. Both extracts gave the same pattern of ribosomal peaks (Fig. 6). Exactly the same peaks, with the same characteristic sedimentation constants, have been found in similarly prepared extracts of a wild type (streptomycin-sensitive) strain of $E$. coli (Bolton et al. 1958). The relative sizes of the peaks attributable to ribosomes in the extract from deprived bacteria are approximately the same as in the extract of normal bacteria, suggesting that streptomycin deprivation had no effect on the quantitative distribution of material among the ribosomal fractions of different molecular weight. It can be seen (Fig. 6) that in the extract of deprived bacteria the total amount of ribosomal material (peaks 1-5) was much larger relative to the total amount of other proteins (p eak 6 ) than in the extract of normal bacteria. This is a necessary consequence of the high RNA content of deprived bacteria and of the unchanged gross intracellular distribution of the RNA.

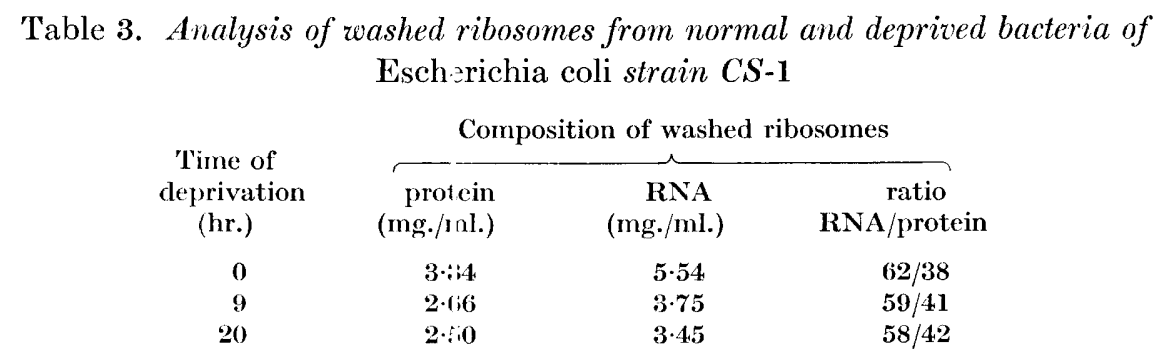

Effects of streptomycin deprivation on enzymic constitution

As just described, a much larger fraction of cellular protein was bound into ribosomes in deprived bacteria than in normal bacteria. Since ribosomal protein is, at least in large part, not enzymically functional, this change of protein distribution necessarily implies that the total enzymic activity of the deprived bacteria must be considerably lower on a veight basis than that of a normal bacterium. The question may therefore be asked, whether the synthesis of all cellular enzymes has been affected to an equal extent, or whether the elfects of streptomycin deprivation on enzyme synthesis are to some extent selective. To examine this question, measurements were made of the relative increase in the activities of a representative group of enzymes during deprived growth. By comparison with the relative increase in the total protein of the bacteria, it was then possible to determine the extent to which the synthesis of each enzyme studied had been affected by streptomycin deprivation. 'Typical data for a few of the enzymes assayed are presented graphically in Fig. 7. It is evident that the effect of streptomycin deprivation on enzyme synthesis was highly selective: for certain enzymes the rate of relative increase in activity closely paralleled the rate of increase of total protein, while for others it was decreased to a greater or lesscr extent. The selective inhibition of the synthesis of certain enzymes became evident only during the transition to arithmetic growth; during the brief initial period of rapid exponential growth, the activities of all the 
enzymes assayed increased at the same rate as did total protein. The values in Table 4 show the extent to which the synthesis of each enzyme studied was affected. In Table 4 the enzymes studied have been classified in three categories: enzymes with a biosynthetic function; enzymes with a function in respiratory metabolism; enzymes without any clearly attributable function under the growth conditions used. With respect to the third class, it should be noted that glycerol was used as carbon source, and that the experiment was conducted with Escherichia coli strain CS-1, in which the synthesis of $\beta$-galactosidase is constitutive.
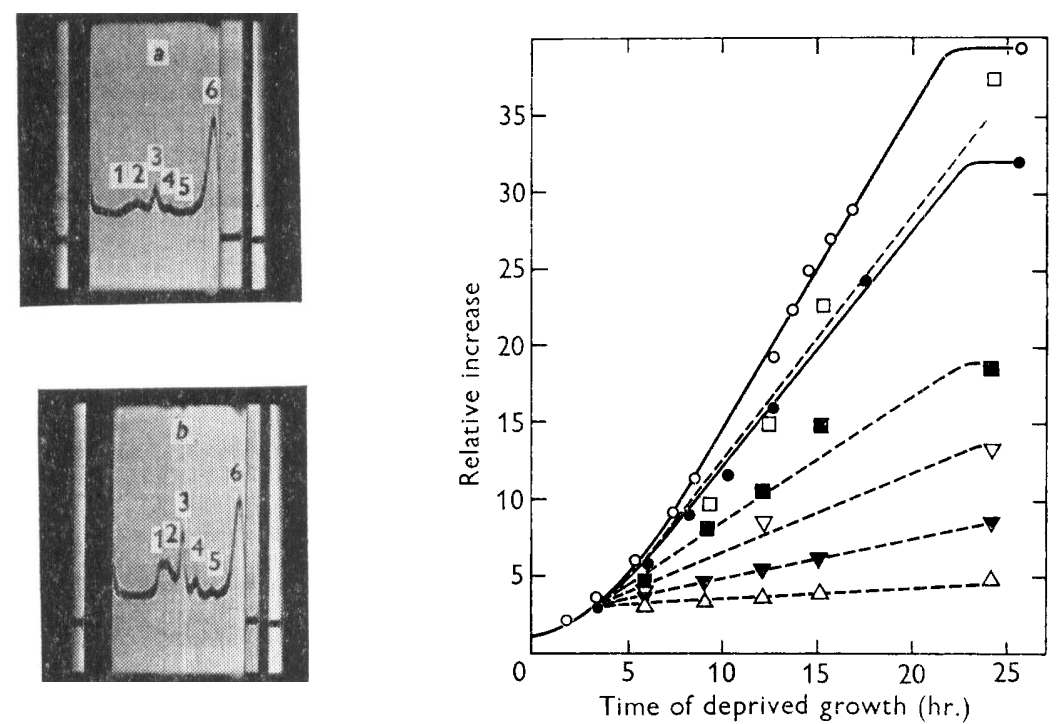

Fig. 6

Fig. 7

Fig. 6. Sedimentation diagrams of crude extracts of normal bacteria of Escherichia coli strain CS-1 $(a)$ and of bacteria of the same strain after $16 \mathrm{hr}$. of deprived growth $(b)$. The peaks are numbered to correspond to the nominal sedimentation constants previously described for $E$. coli: $1,100 \mathrm{~S} ; 2,85 \mathrm{~S} ; 3,70 \mathrm{~S} ; 4,50 \mathrm{~S} ; 5,30 \mathrm{~S} ; 6,4 \mathrm{~S}$. The photographs were taken $8 \mathrm{~min}$. after reaching a final speed of $49,330 \mathrm{rev} . / \mathrm{min}$. Temperature $21^{\circ}$.

Fig. 7 . Increase in the total activity of a selected group of enzymes during deprived growth of Escherichia coli strain CS-1. $(\triangle) \beta$-galactosidase; $(\nabla)$ tryptophan synthetase; $(\nabla)$ succinie dehydrogenase; (a) dihydroorotic dehydrogenase; ( $\square$ ) 5-dehydroshikimic reductase. Solid lines indicate increase in turbidity $(O)$ and in total protein $(\bullet)$ in parallel cultures. Cultures were grown in glycerol defined medium containing $250 \mu \mathrm{g}$. streptomycin $/ \mathrm{ml}$.

Although the number of enzymes studied is admittedly limited, perusal of Table 4 suggests that there was no correlation between the physiological function of an enzyme and the degree to which its synthesis was aflected by streptomycin deprivation. The severe inhibition of the synthesis of the biosynthetic enzyme tryptophan synthetase is in itself sufficient to explain the arithmetic nature of deprived growth. Schaeffer's $(1949 a, 1950)$ observations that the $Q_{0_{2}}$ decreased during deprived growth of streptomycin-dependent bacteria was confirmed for our streptomycin-dependent strains of Escherichia coli. 'This observation is in accord with the substantial inhibition of specific respiratory enzymes shown in Table 4. 
Table 4. The inhibitio 2 of enzyme synthesis by deprived growth of Escherichia coli strain CS-1

Figures represent degree of inhibition in the rate of enzyme synthesis relative to the rate of total protein synthesis. Cultures were grown in defined medium with glycerol as the carbon source.

\begin{tabular}{|c|c|c|c|c|c|}
\hline \multicolumn{2}{|c|}{$\begin{array}{l}\text { Enzymes with a } \\
\text { biosynthetic function }\end{array}$} & \multicolumn{2}{|c|}{$\begin{array}{l}\text { Enzymes functional in } \\
\text { respiratory metabolism }\end{array}$} & \multicolumn{2}{|c|}{$\begin{array}{l}\text { Enzymes with no immediately } \\
\text { apparent function }\end{array}$} \\
\hline Enzyme & $\begin{array}{l}\text { Inhibition } \\
\quad(\%)\end{array}$ & Enzyme & $\begin{array}{l}\text { Inhibition } \\
\qquad \%)\end{array}$ & Enzyme & $\begin{array}{l}\text { Inhibition } \\
\qquad \%)\end{array}$ \\
\hline $\begin{array}{l}\text { 'Threonine } \\
\text { deaminase }\end{array}$ & 0 & $\begin{array}{l}\text { Is jeitric } \\
\text { cehydrogenase }\end{array}$ & 40 & $\begin{array}{l}\text { Glucose-6-phos- } \\
\text { phate dehydro- } \\
\text { genase }\end{array}$ & $\mathbf{5}$ \\
\hline $\begin{array}{l}\text { Dehydroshikimic } \\
\text { reductase }\end{array}$ & 0 & D PNH oxidase & 40 & $\beta$-Galactosidase & 95 \\
\hline $\begin{array}{l}\text { Glutamic } \\
\text { dehydrogenase }\end{array}$ & 50 & $\begin{array}{l}\text { St ccinic } \\
\text { dehydrogenase }\end{array}$ & 60 & & \\
\hline $\begin{array}{l}\text { Tryptophan } \\
\text { synthetase }\end{array}$ & 80 & & & & \\
\hline $\begin{array}{l}\text { Dihydroorotic } \\
\text { dehydrogenase }\end{array}$ & 40 & & & & \\
\hline
\end{tabular}

\section{Effect of streptomycin deprization on the induced synthesis of $\beta$-galactosidase}

The capacity of the inducible strain CS-2 of Escherichia coli to synthesize $\beta$ galactosidase during deprived growth was studied by introducing the inducers isopropyl- $\beta$-D-thiogalactoside (IPTG) and thiomethyl- $\beta$-D-galactoside (TMG) into cultures at various times after the onset of deprivation. As seen in Fig. 8, the inducibility of the organism decined rapidly during deprivation. Inducibility with IPTG was better maintained de ring deprivation than was inducibility with TMG. It should be noted that the entry of TMG into the cell, and consequently its ability to act as an inducer, is depende at on the activity of a specific inducible permease. IP'TG, on the other hand, can enter the cell in the absence of the permease. Consequently $\beta$-galactosidase activities measured after induction with IPTG afford a direct measure of the inducible s,ynthesis of $\beta$-galactosidase alone, whereas activities measured after induction with TMG reflect the synthesis not only of $\beta$-galactosidase, but also of the specific permease. In confirmation of the earlier reports of Polglase (Polglase, Peretz \& Roote, 1956) it is evident that streptomycin deprivation severely affected the capacity of a streotomycin-dependent strain of Escherichia coli to synthesize inducibly $\beta$-galactosidase. In the light of his findings, Polglase assumed that streptomycin deprivation specifically affects the capacity of streptomycindependent organisms to respond to induction. This interpretation now appears to be questionable, since the constitutive synthesis of $\beta$-galactosidase was likewise very severely affected by deprivation, as shown in Table 4 .

\section{Effect of streptomysin deprivation on lysogenic induction}

The production of phage by a lysogenic organism requires both the expression of genetic information, and the s.rnthesis of considerable amounts of biologically active DNA. The maintenance of DNA function during streptomycin deprivation can therefore be to some extent assessed by examining the ability of the bacteria 
to support phage development. Accordingly the capacity of deprived bacteria of Escherichia coli strain W1709 to produce phage $\lambda$ following ultraviolet (u.v.) irradiation was investigated. Even after $9 \mathrm{hr}$. of deprivation, the bacteria responded to induction by lysis, with the release of infectious particles. When u.v. induction was applied at various times during the course of streptomycin deprivation, a progressive lengthening of the latent period and a decline in burst size were observed. These effects are probably best explained as resulting from a general decline in the capacity for cellular syntheses, rather than from any specific effect of deprivation on the process of phage formation.

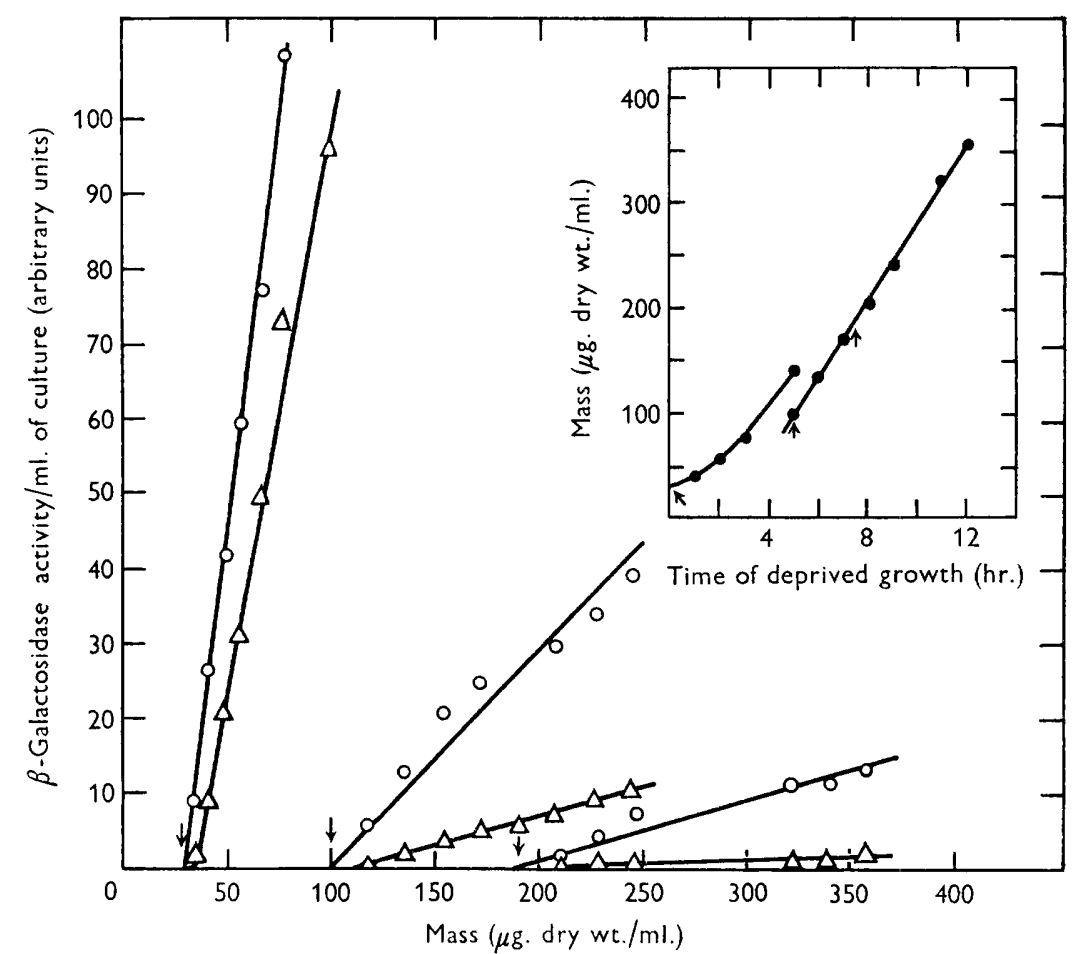

Fig. 8. Induction of $\beta$-galactosidase during deprived growth of Escherichia coli strain CS-2. Total activity $/ \mathrm{ml}$. culture after addition of IPTG $(O)$ or TMG $(\triangle)$ each at $5 \times 10^{-4} \mathrm{M}$ is plotted as a function of cell mass. Inset shows growth of parallel cultures. Time of addition of inducers indicated by arrows.

\section{Recovery}

When streptomycin was added to a deprived culture, there was a lag before the rate of increase in turbidity returned to the normal exponential value. The length of this lag was directly proportional to the length of time during which the bacteria had been deprived; it was as little as a few minutes when streptomycin was added early in the arithmetic phase, or it was as long as 6-8 hr. when streptomycin was added toward the end of the arithmetic phase. The cellular changes which accompanied recovery are illustrated in Figs. 9 and 10 for a culture of Escherichia coli strain W 1709 which was given streptomycin late in the course of arithmetic deprived growth. After the addition of streptomycin, the number of colony-forming units 
remained constant for about $2 \mathrm{hr}$. It then increased rapidly until the relationship between turbidity and viable count characteristic of a normal exponentially growing population had been attained (Fig. 9). As shown by direct microscopic examination, the rapid rise in viable count was preceded by the transformation of the filaments into chains of bacter a, and was accompanied by the fragmentation of those chains. Once an exponential growth rate had been re-established, only very rare filaments were detected in the culture by microscopical examination.

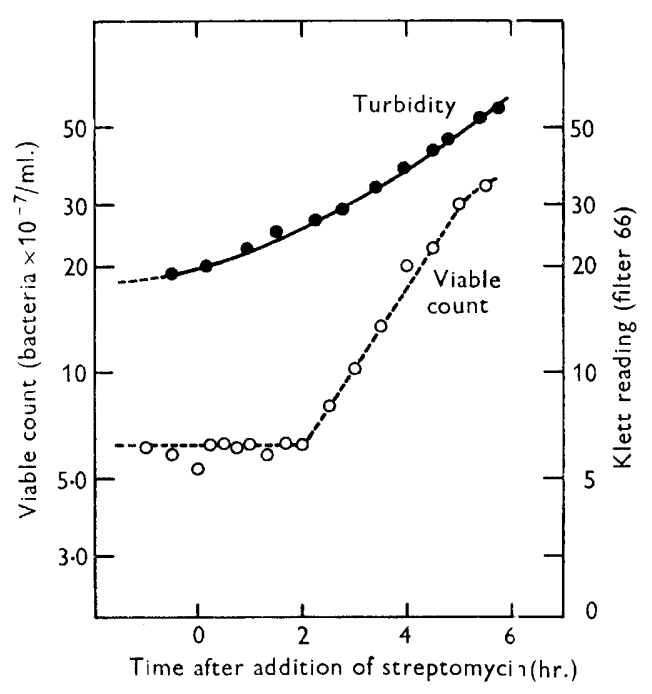

Fig. 9

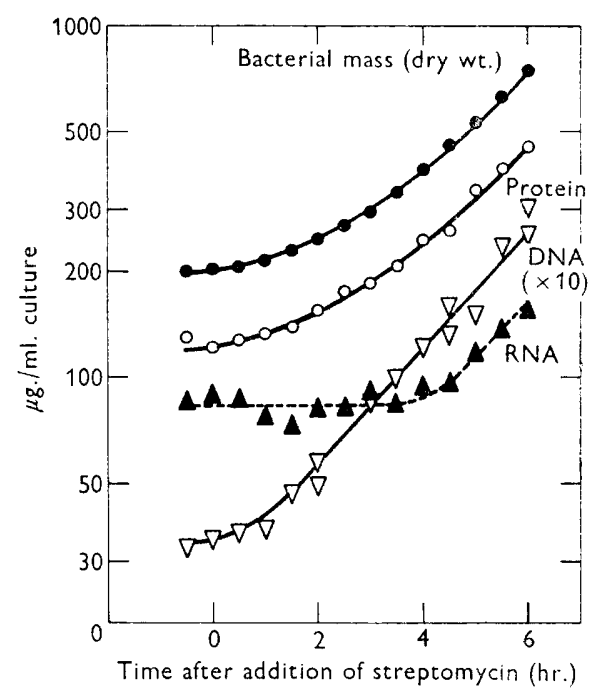

Fig. 10

Fig. 9. Increase in colony-forming units in a culture of Escherichia coli strain CS-1 during recovery after $16 \mathrm{hr}$. of deprived growth. Streptomycin was added at time 0 at $250 \mu \mathrm{g} . / \mathrm{ml}$.

Fig. 10. Increase in RNA, DNA, cell mass and protein in a culture of Escherichia coli strain CS-1 during recovery after $16 \mathrm{hr}$. of deprived growth. Streptomycin was added at time 0 at $250 \mu \mathrm{g} . / \mathrm{ml}$.

The restoration of normal macromolecular composition in the bacteria during recovery involved a distinctive pattern of synthesis (Fig. 10). Following the addition of streptomycin, the rate of synthesis of DNA soon increased to its normal exponential value. The rate of protein synthesis also began to increase soon after the addition of streptomycin, but approached more slowly its normal exponential value. Net synthesis of RNA did not take place until the RNA content of the bacteria had decreased to its normal value as a result of preferential synthesis of the other components of the cell. As soon as this value was reached, RNA synthesis resumed at the normal exponential rate.

\section{DISCUSSION}

Previous studies on streptomycia-dependent bacteria have led to two suggestions about the manner in which streptomycin maintains the normal functioning of a dependent organism. Schaeffer (19.52) suggested that streptomycin is required either for the synthesis or for the functicn of the particulate centres of respiration in the 
cell. Polglase et al. (1956) proposed that streptomycin is specifically required for the synthesis of inducible enzymes. The results which we report here make possible a somewhat broader assessment of the way in which streptomycin regulates the enzymic constitution of streptomycin-dependent organisms. When streptomycin becomes limiting an enzymic imbalance, which affects all classes of enzymes in the cell, becomes established. This imbalance is a consequence of the fact that the synthesis of some specific enzymes is either partly or wholly suppressed by a lack of streptomycin, whereas the synthesis of others continues at a normal differential rate. The selective effects of streptomycin deprivation on enzyme synthesis seem to be random, when examined in terms of enzymic function. There is no reason to believe that the inducibility of constitutivity of an enzyme has any bearing on the way its synthesis will be affected by deprivation.

We also found that streptomycin deprivation had a major effect on the RNA metabolism of the cell. It caused a marked enhancement of the differential rate of synthesis of RNA, which resulted in the overproduction of soluble and ribosomal RNA. As judged by relatively gross criteria, deprivation did not, however, affect the intracellular state of RNA, which cannot be so far distinguished from that in a streptomycin-dependent organism grown with a critical concentration of streptomycin, or in a sensitive organism grown without streptomycin.

The remaining effects which accompanied streptomycin deprivation can be interpreted as secondary consequences of the enzymic imbalance characteristic of the deprived organism. The differential rate of DNA synthesis began to decline markedly only when streptomycin had become severely limiting. Even under these circumstances, nuclear division continued, and the DNA that was synthesized was still functional (as shown by the ability of the deprived lysogenic cell to produce active phage upon induction). There was no cellular lysis or leakage of cellular constituents during deprivation, which suggests that the formation of a normal cell wall and cell membrane continued. Although the specific factors which lead to the cessation of cell division are not known, this consequence of deprivation can also be plausibly regarded as a secondary one. Cell division is readily inhibited by adverse environmental conditions, and many inhibitory agents which differ from one another in their primary mode of action on the organism (e.g. u.v. irradiation, penicillin, mitomycin ( ) share the common property of blocking cell division.

We are accordingly left with only two biochemical effects which can be considered to stem specifically and more or less directly from the withdrawal of streptomycin: the partial or complete suppression of the synthesis of many enzymes; the high differential rate of synthesis of all forms of RNA. Taken in conjunction, these two elfects suggest that in the streptomycin-dependent organism streptomycin plays a role at some point in the interrelated processes of protein and RNA synthesis.

To make a more specific inference about the location of streptomycin action, we must consider the implications of the quantitative effects of streptomycin on the growth of streptomycin-dependent organisms. The first of these is the extremely regular correlation of the exponential growth rate with streptomycin concentration over a wide range of concentrations, and its abrupt change to insensitivity at the critical concentration. The second is the quantitative relation of deprived growth to the concentration of streptomycin to which the streptomycin-dependent organisms were previously exposed. The existence of this relationship with respect to the 
extent of residual cell division was first shown by Demerec et al. (1949). We have found a similar relationship with respect to the duration and the extent of residual exponential growth. The interpretation of all these facts has become easier with the discovery that the streptorycin-dependent cell can bind streptomycin irreversibly, and that growth with a supra-critical concentration of streptomycin results in the binding of this compound in two forms distinguishable by the means required to extract them from the cells.

It is difficult to avoid the conclusion that the streptomycin-dependent organism contains a number of specific sites, all of which must be combined with streptomycin for the maintenance of normal cellular function. The critical concentration of streptomycin can then be interyreted as that external concentration which just suffices to keep all the specific sites within a growing population combined with streptomycin. At subcritical concentrations, the external streptomycin concentration is too low to saturate all the internal specific sites, and the bacteria suffer a functional impairment which is \&rossly expressed as exponential growth at a submaximal rate. At supra-critical concentrations, the bacteria contain more streptomycin than the amount requirel to saturate the specific sites, and consequently possess an internal pool, the size of which is directly related to the external streptomycin concentration. Our data or streptomycin binding by streptomycin-dependent organisms grown with a supra-critical concentration of streptomycin fit very well with this assumption. The fraction of bound streptomycin which can be extracted from the organisms with hot wa er might be considered to represent the streptomycin of the internal pool, and the fraction extractable only with hot perchloric acid to represent the streptomy in bound to specific sites. It should be noted, however, that even the former fraction is not able to diffuse out of the cell, since it cannot be exchanged with external streptomycin. The internal pool is therefore probably not a 'free' one, but is non-specifically bound by other internal constituents of the cell.

The quantitative aspects of deprived growth by streptomycin-dependent organisms previously grown with a supra-critical concentration of streptomycin can be explained on the basis of the assumptions made in the last paragraph. Under conditions of deprivation, the non-diffusible internal pool of streptomycin can be drawn upon to saturate newly formed specific sites. Normal growth and function can thus be maintained for a limited period, the duration of which is proportional to the size of the internal pool, which is in turn a function of the external concentration of streptomycin to which the organism had been previously exposed.

Is it possible to make any inferences concerning the nature of the postulated specific sites from the available data? In view of the magnitude of streptomycin binding by the streptomycin-dependent organism, we suggest that the number of specific sites is large: i.e. of the order of $10^{4}$ to $10^{5}$. Each streptomycin-dependent bacterium contains about 120,000 molecules of firmly bound streptomycin, not extractable by hot water. Even if we assume that several of these molecules are attached to each site, the number of sites must therefore be relatively great. A second inference about the sites can be drawn from our observations about the critical concentration of streptomycin. Under any given set of environmental conditions, this critical concentration was constant, but its magnitude changes with the nature of the carbon source. The critical concentration was considerably higher 
for glucose, the carbon source which supports the highest growth rate of Escherichia coli, than for succinate and glycerol which support lower (and similar) growth rates. Since we interpret the critical streptomycin concentration as that concentration which is just sufficient to saturate all the specific sites in the organism, it follows that the number of specific sites in each organism is not absolutely fixed, but can fluctuate within certain limits in response to a change in the nature of the carbon source.

Both these inferred properties of the specific combining sites can be explained by the hypothesis that they are the ribosomes. We accordingly propose that the miscellaneous biochemical and physiological peculiarities of a streptomycin-dependent organism ultimately reflect a genetic impairment of ribosomal structure, the functional consequences of which can be specifically overcome by combination of the ribosomes with streptomycin. The postulated impairment of structure must obviously be a minor one (perhaps the change of a single amino acid in the ribosomal protein) since the ribosomes of streptomycin-dependent organisms showed no gross abnormalities of composition or sedimentation behaviour.

Under conditions of streptomycin deprivation, impaired ribosomal function causes an imbalance in the pattern of enzyme synthesis, coupled with a decline in the rate of gross protein synthesis. This, in turn, provokes an over-production of RNA through the derangement of the feed-back control mechanism which normally keeps protein and RNA synthesis in metabolic balance. We shall not further develop the strictly biochemical aspects of this hypothesis here, since they are treated at length in another paper, which is devoted to a general theoretical interpretation of streptomycin sensitivity, resistance and dependence in bacteria (Spotts \& Stanier, 1961).

The author wishes to thank Dr M. Pon for assistance with the ultracentrifugal work, Dr A. J. Clark for assistance with the genetic and bacteriophage studies, and Professor R. Y. Stanier for advice and encouragement during the work, and for helpful criticism during the preparation of the manuscript. This work was carried out during the tenure of a Predoctoral Fellowship from the National Institute of Allergy and Infectious Diseases, United States Public Health Service, and formed the basis of a dissertation submitted in partial satisfaction of the requirements for the Ph.D. degree at the University of California, Berkeley, California, U.S.A.

\section{REFERENCES}

Barban, S. \& AJl, S. (1952). Triphosphopyridine nucleotide linked isocitric dehydrogenase in bacteria. J. Bact. 64, 443.

Bertani, G. (1951). A method for detection of mutations using streptomycin dependence in Escherichia coli. Genetics, 36, 598.

Bolton, E. T., Britten, R. J., Cowie, D. B. \& Roberts, R. B. (1958). Yearb. Carneg. Instn, 57, 127 .

Bolton, E. T., Britten, R. J., Cowie, D. B., McCarthy, B. J., McQuillen, K. \& Roberts, R. B. (1959). Yearb. Carneg. Instn, 58, 259.

Burton, K. (1956). A study of the conditions and mechanism of the diphenylamine reaction for the colorimetric estimation of deoxyribonucleic acid. Biochem. J. 62, 315.

Delaporte, B. (1949). Yearb. Carneg. Instn, 48, 166.

Demerec, M., Wallace, B., Witkin, E. M. \& Bertani, G. (1949). Yearb. Carneg. Instn, 48, 154 . 
DEMoss, R. D. (1955). Glucose-6-phosphate and 6-phosphogluconic dehydrogenases from Leuconostoc mesenteroides. In Methods in Enzymology, vol. I, p. 328. Edited by S. P. Colowick \& N. O. Kaplan. New York: Academic Press, Inc.

Engelberg, H. \& Artman, M. (1961). Studies on streptomycin dependent bacteria : effect of growth in limiting amounts of streptomycin on respiration and fermentation of a streptomycin dependent mutant of $\boldsymbol{E}$. coli. Biochim. biophys. Acta, 47, 553.

Hashimoto, K. (1960). Streptomycin resistance in Escherichia coli analysed by transduction. Genetics, 45, 49.

Lederberg, J. (1950). The beta-D-galactosidase of Escherichia coli strain K-12. J. Bact. 60, 381 .

LENNox, E. S. (1955). 'Transduction of linked genetic characters of the host by bacteriophage P1. Virology, 1, 190.

Lowry, O. H., Rosebrough, N. J, Farr, A. L. \& Randall, R. J. (1951). Protein measurement with the Folin phenol reagent. J. biol. Chem. 193, 265.

Matney, 'T. S., Goldschmidt, E. P. \& Bausun, H. T. (1960). Genetic analysis of streptomycin dependent mutants of Salmonella typhimurium. Bact. Proc. p. 186.

Miller, C. P. \& BohnhofF, M. (194\%). 'Two streptomycin-resistant variants of meningococcus. J. Bact. 54, 467.

Newcombe, H. B. \& Nyнод, M. H. (1950). The inheritance of streptomycin resistance and dependence in crosses of Escherichia coli. Genetics, 35, 603.

Paine, Jun., 'T. F. \& Finland, F. (1948). Observations on bacteria sensitive to, resistant to and dependent upon streptomy cin. J. Bact. 56, 207.

Pardee, A. B. \& Prestridgk, I. S. (1955). Induced formation of serine and threonine deaminases by Escherichia coli. J. Bact. 70, 667.

Polglase, W. J., Peretz, S. \& Roo're, S. M. (1956). Adaptive enzyme formation by dihydrostreptomycin-dependent Fischerichia coli. Canad. J. Biochem. 34, 558.

Price, C. A. \& Thimann, K. V. (19:44). The estimation of dehydrogenases in plant tissue. Plant Physiol. 29, 113.

Rubin, B. A. \& Steinglass, P. (1951). The recovery of streptomycin from cultures of streptomycin requiring mutants of Escherichia coli. Bact. Proc. p. 33.

Scrafflen, P. $(1949 a)$. Divorce en tre croissance et respiration chez un Bacillus subtilis exigeant et carence en streptomy ine. C.R. Acad. Sci., Paris, 228, 440.

SchatfFer, P. (1949b). Influence de la carence en streptomycine sur la fermentation anaérobie du glucose par une souche streptomycine-exigeante de Escherichia coli. C.R. Acad. Sci., Paris, 229, 1032.

Schaffrer, P. (1950). Croissance et respiration d'une souche streptomycine-exigeante de Bacillus cereus privée de l'antibiotique facteur de croissance. Ann. Inst. Pasteur, 78, 624 .

Schafffer, P. (1952). Recherche sur le métabolisme bactérien des cytochromes et des porphyrines. IV. Effects de la carence en streptomycine sur des mutants bactériens streptomycine-exigeants. Biochim. biophys. Acta, 9, 563.

Schneider, W. C. (1957). Determination of nucleic acids in tissues by pentose analysis. In Methods in Enzymology, vol. I.I, p. 680. Edited by S. P. Colowick \& N. O. Kaplan. New York: Academic Press, Inc.

Sımon, E. (1955). Bacteriological, immunological and genetical studies with streptomycindependent bacilli. Ph.D. thesis, Iniversity of Wisconsin.

Slater, E. C. (1950). 'The components of the dihydrocozymase system. Biochem. J. 46, 484.

Slater, E. C. \& Bonner, W. D. (1952). The effect of fluoride on the succinic oxidase system. Biochem. J. 52, 185.

Spotr's, C. R. \& Stranier, R. Y. (1961). The mechanism of streptomycin action on bacteria: a unitary hypothesis. Nature, Lomd. 192, 633.

Strkcker, H. J. (1955). L-Glutimic acid dehydrogenase from liver. In Methods in Enzymology, vol. II, p. 220. E1. by S. P. Colowick \& N. O. Kaplan. New York: Academic Press, Inc.

Szybalski, W. \& Mashima, S. (19:9). Uptake of streptomycin by sensitive, resistant and dependent bacteria. Biochem. Biophys. Res. Comm. 1, 249. 
Tissières, A., Watson, J. D., Schlessinger, D. \& Hollingworth, B. R. (1959). Ribonucleoprotein particles from Escherichia coli. J. mol. Biol. 1, 221.

Watanabe, 'T. \& Watanabe, M. (1959a). Transduction of streptomycin resistance in Salmonella typhimurium. J. gen. Microbiol. 21, 16.

Watanabe, T. \& Watanabe, M. (1959b). Transduction of streptomycin sensitivity into resistant mutants of Salmonella typhimurium. J. gen. Microbiol. 21, 30.

YanIV, H. \& Gilvarg, C. (1955). Aromatic biosynthesis. XIV. 5-Dehydroshikimic reductase. J. biol. Chem. 213, 787 .

Yanofsky, C. (1955). Tryptophan synthetase from Neurospora. In Methods in Enzymology, vol. II, p. 233. Ed. by S. P. Colowick \& N. O. Kaplan. New York: Academic Press, Inc.

Yates, R. A. \& PARdeE, A. B. (1957). Control by uracil of enzymes required for orotate synthesis. J. biol. Chem. 227, 677. 